Working Paper Number 186

\title{
Anthropological Encounters with Economic Development and Biodiversity Conservation
}

Laura M. Rival*

Current debates on the ecological crisis and on shared responsibilities for the maintenance of the earth's commons raise fundamental anthropological questions, but anthropologists have yet to engage fully with them, or with the paradigm of sustainable development. This chapter offers a personal account of encounters between anthropology, biodiversity conservation, and economic development. Authors examining the links between biological and cultural diversity are reviewed, and recent studies of conservation and development policies critically assessed.

\section{KEY WORDS}

Biological and cultural diversity. Agroecology. Development and conservation policies. Economics and ecology.

\section{January 2011}

* Queen Elizabeth House, University of Oxford

Laura Rival is Lecturer in the Anthropology of Nature, Society and Development. This paper was initially prepared for the ASA Handbook of Social Anthropology to be published by Sage in 2012. 
I grew up with the idea of development, but had to wait until 1993 for my first encounter with the idea of biological diversity. ${ }^{1}$ I had just started a post-doctoral fellowship at Oxford where I met Darrell Posey who was, by then, deeply immersed in the politics of developing intellectual property rights protocols for indigenous peoples in relation to the newly signed Convention on Biological Diversity (CBD). I accepted his offer to contribute to a book he was preparing on the cultural and spiritual values of biodiversity (Posey 1999). In his foreword to the book, Klaus Töpfer ${ }^{2}$ explains why biodiversity must be protected from development:

As we approach the next millennium, 'globalization' has become the dominant tendency [...] The positive aspects of such a trend are numerous [...] However, the trade-offs are less well understood, and among these the impacts of the predominant development model on the global environment should be a major concern for us all. Climate change, loss of biodiversity, depletion of the ozone layer, pollution, exhaustion of water resources, and conflicts over shared resources are some of the most pressing problems faced by humankind. There is strong evidence that the life support systems on which our economies depend are being overloaded [...] Besides the profound ethical and aesthetic implications, it is clear that the loss of biodiversity has serious economic and social costs [...] Placing a monetary value on species and ecosystems may be a useful exercise by which to integrate the cost of using and conserving biodiversity into the current global economic system, but it will never be possible to comprehend the true value of life in such a system. Respect for

\footnotetext{
${ }^{1}$ For the idea of development, see Cooper and Packard (1997), Cowen and Shenton (1996), and Crush (1995). The term biological diversity was coined in 1980 (Farnham 2007: 9) and shortened to 'biodiversity' at a forum sponsored by the National Academy of Sciences and the Smithsonian Institution, which E. O. Wilson organised in 1986 (Escobar 2008: 341), and which formed the basis for the book Wilson edited in 1988.

${ }^{2}$ Klaus Töpfer was UNEP's Executive Director at the time. UNEP is the United Nations Environmental Programme (http://www.unep.org/). UNEP will be coordinating the Intergovernmental Platform on Biodiversity and Ecosystem Services (IPBES) set up as a mirror of the Intergovernmental Panel on Climate Change (IPCC) adopted by the United Nations 65th General Assembly (UNGA) on 21 December 2010.
} 
biological diversity implies respect for human diversity. Indeed, both elements are fundamental to stability and durable peace on earth.

The contradiction between economic development and biodiversity conservation has only deepened since the publication of this book, and scientists have continued to express their concern in major reports such as the Millenium Ecological Assessment (2005), in which some anthropologists participated (Filer 2009, Norgaard 2008), or in pronouncements such as the 2007 Kaua'i declaration. In this declaration, ethnobotanists, anthropologists and 'people from associated disciplines' consider 'the grave environmental crisis facing the world today, the loss of biodiversity and the loss of culture,' and stress the need to use scientific knowledge to provide 'some of the solutions towards more sustainable living:'

If plants did not exist, human life would not be possible. Today we also depend on them for many of our opportunities to improve the quality of human life in the future. Plants are fundamental to the functioning of all human societies and to the operation of all ecosystems. The application of ethnobotany is a possible way of breaking free of our passive approach to the world and dealing with this seemingly overwhelming set of challenges in a positive way. Ethnobotany is at once a vital key to preserving the diversity of plants as well as to understanding and interpreting the knowledge by which we are, and will be, enabled to deal with them effectively and sustainably throughout the world. Thus ethnobotany is the science of survival.

As these two quotes illustrate, the idea of biological diversity invites us to act to ensure that natural resources are used at a rate slower than that at which they have been created. By putting older ideas of nature into new conceptual frames, biodiversity, an idea woven from diverse strands, changes 'how people far and near see the natural world, value the natural world, and therefore treat the natural world' (Takacs 1996: 338). What does this drive to slow environmental destruction tell us about processes of change and social transformation? And 
how has anthropology contributed to an understanding of mobilisations to contain the forces of development?

Such big questions can only be answered partially here. I start with a brief account of a recent meeting jointly organised by conservation biologists and anthropologists, which illustrates how efforts to integrate the social and natural sciences are shaping new research agenda, before outlining two of them. While the first explores the links between biological and cultural diversity, the second analyses proposals to value and govern diversity. Both aim at documenting the ways in which the complex and dynamic ideas of development and biodiversity are being shaped, interpreted, contested and negotiated in different places around the world today. Although necessarily multi-disciplinary, these two areas of research equally show the continuing relevance of anthropological approaches for the study of the ways in which knowledge is produced and used in the act of governing nature and society. I end with a few reflections on the theoretical, methodological and ethical challenges faced by anthropologists in an era when increasing economic resources are being committed to the preservation of biological diversity, amidst intensified political negotiations.

\section{'Sustaining Cultural and Biological Diversity in a Rapidly Changing World'}

I was invited in April 2008 to address a four-day symposium organised by the American Museum of Natural History (AMNH) on the theme 'Sustaining Cultural and Biological Diversity in a Rapidly Changing World: Lessons for Global Policy.' Participating in this event made me fully aware of the extent to which the idea of biodiversity had embedded itself in my work. The meeting was co-organised by the museum's Centre for Biodiversity and Conservation, the World Conservation Union's Commission on Environmental, Economic and Social Policy (IUCNCEESP), Terralingua, ${ }^{3}$ the Wenner-Gren Foundation, and The Christensen Fund. ${ }^{4}$

\footnotetext{
3 An NGO (http://www.terralingua.org/) defending linguistic diversity as a means, in its own words, 'to sustain the biocultural diversity of life.'
} 
The purpose of the symposium was to assess progress made by natural and social scientists in recognizing 'the interconnectedness of natural and cultural processes,' both in scientific inquiry and in policy, and to explore ways of translating an awareness of the threats such processes are facing into actions that would stem 'the mounting erosion of the diversity of life in all its manifestations.' Panels covered a wide range of themes from endangered languages and traditional ecological knowledge, indigenous peoples and climate change, agrobiodiversity, eco-cultural health, and the ethics of valuing nature. Each day started with indigenous testimonies in sessions called 'Voices from around the World.'

Around 130 delegates had been invited to participate in the symposium, amongst whom I counted 27 anthropologists and linguists. ${ }^{5}$ Who was trained in what discipline did not really matter, however, in the ebullience of coming together and the hope of making a difference. There seemed to be broad agreement among delegates that survival will depend on the realization that humans, far from being separate from the rest of nature, form an integral and critically important part of biodiversity (Redford and Brosius 2006). By merging social and biological approaches, conservation scientists were thus proposing to rewrite the three-tiered definition identifying genes, species and ecosystems as the hierarchical levels of biological diversity, so that it would now incorporate cultural factors, as well as economic, political and social ones. Delegates agreed that this radical broadening of the notion of biological diversity required a sustained understanding of: (1) bioculturalism as 'a major conceptual step towards re-entwining the domains of nature and culture whereby value is not determined by what can be bought, sold and monetarily profited from' (Sian

\footnotetext{
${ }^{4}$ Ken Wilson, Executive Director of the Christensen Fund chaired the panel 'Funding Opportunities for Sustaining Biological and Cultural Diversity.' He explained that the fund, which had for many years purchased art works to donate them to museums, where they could be enjoyed by a wide public, was now dedicated to funding the 'custodians of biocultural diversity who maintain beauty in their lived landscapes.'

5 This number does not include the representatives of conservation and development organisations trained in anthropology, or the delegates trained in both anthropology and in environmental sciences.
} 
Sullivan, an anthropologist); (2) the earth as 'an emergent property of life itself' (Jules Pretty, a geographer); and (3) diversity arising from 'natures and cultures [as] emergent properties of localised alternative actions' (Eleanor Sterling, a biologist). Disagreements remained, however, on which epistemology should frame such integration, 'material realism' or 'social constructivism'. There was also discussion of the desirability of returning to systemic modes of analysis.

The choice by the symposium's organizers to engage the diversity of nature with one specific human component, i.e. cultural difference as revealed by language, was the source of much debate as well. ${ }^{6}$ The scientific validity of the 'biocultural diversity' concept was probed in a background paper prepared especially for the panel 'The Cultural Politics of Sustaining Cultural and Biological Diversity' (Graef et al 2008). There were also critiques of the symposium's peripheral treatment of economic and political factors. How could the paradigm of biodiversity conservation be strengthened through the inclusion of cultural diversity and its preservation, while leaving aside the thorny issue of economic development? A number of delegates and participants mentioned the need to research the power structures through which global policy agenda get shaped, as well as the macroeconomic structures that destroy both natural environments and human communities. Other delegates stressed the importance of collective action to reform development and conservation policies. Someone simply asked: For whom should biodiversity conservation be sustained? A delegate from Papua New Guinea noted the value shift that had occurred in the country in less than one generation, resulting in the local adoption of a "resource view of nature": 'resources are to make money with. People want to sell their resources; they want the right to use their resources as they wish. This is a problem for conservation work. It's difficult to build alliances where there is mistrust, and where clans are divided.' A Maori environmental lawyer presented concrete examples of how indigenous claims to resource control and autonomy, often negatively portrayed by mainstream society, were promoting benefits for

\footnotetext{
6 The symposium's theme directly related to a volume edited by Terralingua's co-founder and president, Luisa Maffi, which explored the links between language, knowledge and the environment (Maffi 2001).
} 
all: 'Maori fight the government in a way that benefit the whole society by campaigning, for example, against the discharge of raw sewage in the sea [...] Native claims can translate into new environmental policy. We need to think about the management of nature in terms of citizen rights. Before you move forward, you have to deal with the legacies of the past.'

I was asked to intervene in the panel 'The Role of Social Scientists in Critical Civic Issues.' My presentation was based on a small inter-cultural exchange I had just organised at the demand of Huaorani friends. In the spring of 2006, I revisited the community of Toñampari in order to collect additional data for my chonta palm management study (Clement, Rival and Cole 2009). During my visit, the first in twelve years, parents told me 'our children are not learning' because the school 'works against the forest.' [...] 'We want to build a different education system for our children.' To help villagers in this endeavour, I offered to organise a visit with a Maya Kakchiquel activist from Guatemala, whose project of cultural revitalization and land restoration had impressed me deeply. Although the visit lasted only ten days, much happened during our short stay. At the villagers' request, we started each day by teaching English in one of the school's classrooms. Participating children and adults were fascinated by the variety of English accents we used when teaching them the basic vocabulary and phrases they wanted to learn. They were aware of my French accent, whether in Huaorani, Spanish or English, and curious about the Spanish used by my Guatemalan friend. The day was spent visiting gardens and fields, comparing planting techniques and soil quality, and inventorying crop varieties. There were lively discussions about plant cultivation, and many other topics. Children who were not at school took us on forays in the forest surrounding the village, each foray yielding an abundance of fruits. In the evenings, the whole village would assemble to listen to my Mayan friend's stories, asking him a myriad of questions about life in his village and in Guatemala, welcoming each answer with cascading jokes and bursts of laughter. We created a small 'Mayan garden' near the school, and distributed the remaining seeds to cultivators who wanted to try them out in their own gardens. We talked about what the new school could be like, about the links between soil fertility and snakes, and about the powers of the moon and the 
river. Small gifts of plants, flowers, seed necklaces, and food were exchanged. News of this visit quickly spread in Huaorani land, and I soon received requests from other villages for more visits. This success was undoubtedly due to the Huaorani's insatiable curiosity for foreign ways. However, it was the first time that a 'small dark foreigner' from Guatemala had come to visit. His stories had not been heard before. There was anticipation mixed with apprehension at the thrilling thought that a return visit to his community may be organised in the future.

I then tried to explain as self-reflectively as I could how this visit had come to represent a form of civic engagement, one which critically engaged my professional expertise in cultural difference, while implicating me as a citizen concerned with the negative impacts of the oil frontier in the Ecuadorian Amazon. The changes occurred in Huaorani society and culture over the last thirty years illustrate the symbolic violence exercised by dominant society, which cannot recognize the value (let alone the right) of being different and of living in a distinct human collectivity. My career as an anthropologist working among various indigenous communities in Latin America had, I explained, convinced me that one of the biggest challenges for policy makers in the $21^{\text {st }}$ century is to create opportunities so that people need not renounce their identities in order to have access to the full range of social and economic possibilities. It also taught me that the global ecological challenges the world faces in the $21^{\text {st }}$ century will not be solved by 'top-down' solutions or unidirectional 'harvesting' of knowledge. Instead, genuine exchange needs to be fostered between those who retain an understanding of the ecological and cultural specificity of their environments and researchers seeking to understand the web of relations between ecology, culture and history. Although their goals are seemingly opposed, economic development and biodiversity conservation interventions may in fact be very similar in the way they are conceptualised, financed and planned. This is why, I concluded, anthropologists, through their indefatigable efforts to deconstruct dominant discourses and to document forms of knowledge and intelligent practices often invisible to other scientists (whether because they are ordinary, marginalised or subaltern), continue to play an 
important role in creating the conditions for democratic debate on what to conserve or what to develop, for whom, and how. This admirable goal, however, is becoming more difficult to achieve, as phronesis is harder to sustain in a world become less consensual, and more polarised. If social scientists no longer have to make their science matter (Flyvbjerg 2001), they still need to confront those who determine what kind of scientific evidence matters as guide to action. Such dilemmas, themselves good indicators of the changing conjuncture, are not new. Issues of engagement (Spencer 2010, Howell 2010) were already faced by previous generations of anthropologists, who had to take sides, rather than just studying how sides were being taken, on, for instance, the legitimacy of national liberation movements (e.g. Asad 1973).

\section{The biological diversity of wild and cultivated nature}

In his address to the AMNH Symposium, Ashish Kothari, who works for IUCN (the International Union for Conservation of Nature), explained recent changes in conservation thinking. To conserve vast areas of pristine wilderness kept beyond human reach was no longer considered to be the most effective way of protecting biodiversity. The shift from 'PAs' (protected areas) to 'CCAs' (community conservation areas) was endorsed a few months later at the Barcelona World Conservation Congress. ${ }^{7}$ Ashish Kothari expressed his confidence that the new paradigm of conservation practice 'across landscapes and seascapes' would preserve biodiversity 'in more than just islands of protection in the midst of destruction,' while ensuring a fuller integration in conservation thinking of the rights of indigenous and traditional peoples to livelihood and culture. ${ }^{8}$ He outlined the main features of a sustainable mode of livelihood, which he defined as a way of life compatible with the conservation of biodiversity, remarking that such features were characteristic of 'indigenous

\footnotetext{
7 The 2008 World Conservation Congress (WCC) marked IUCN's 60th anniversary (see http://www.iucn.org/).

${ }^{8}$ For anthropological analyses of IUCN conservation policies, and the model of 'community-based resource management' through 'participatory conservation,' see Brosius and Campell (in press), Paulson et al (in press), Doolittle (ms), and Brosius (2004). As always, the issue is to determine whether such new attempts at integrating conservation and development are imposed from without, embraced from within, or negotiated in fairness (Brosius et al 2005).
} 
conserved areas.' In indigenous conserved areas, he added, community rules work more effectively than top-down government regulations, which brought him to conclude that 'there is no contradiction between ecosystem conservation and sustaining livelihoods [...] Ecosystem values are realised through the diversity of knowledge systems [...] This is how rights and conservation worldviews will be reconciled, [...] away from PA-centrism. ${ }^{9}$ Conservationists, it seemed, had finally recognized a fact familiar to anthropologists, i.e. that social groups and individuals may modify ecosystems in ways that actually enrich, rather than degrade, biological diversity (e.g. Balée 2006, Rival 2006).

Comparing the new vision outlined by Ashish Kothari (see also Dressler et al 2010) with Wilson's (1985) seminal paper “The Biological Diversity Crisis: A Challenge to Science' highlights what has changed in biodiversity thinking over the last twenty-five years, and what has not. Today's policy recommendations, like then, are guided by more than the biology of the origination of diversity and extinction, for the conservation of biology cannot be separated from social, cultural and political factors (Adams et al 2004). If some awareness of the great variation in how humans and their cultures influence biodiversity was already present in Wilson's writings, this awareness is being reshaped today by the positive valorisation of indigenous and traditional ways of life in terms of their supposed biodiversity-enhancing effects. The more we move away from the conservation agenda of 'the rich,' with its alleged focus on mega-fauna and endangered species, the closer we get to the 'environmentalism of the poor' (Martinez-Alier 2002, Guha and Martinez-Alier 1997), born out of, we are told, the very materiality of their livelihoods, a concept now being actively reappropriated (and fought over) by both socio-ecological movements and 'REDD+' advocates. ${ }^{10}$ As poor rainforest dwellers are often 'indigenous,' the

\footnotetext{
${ }^{9}$ This line of thought is particularly well illustrated in the special issue entitled 'Indigenous Intelligence, Diverse Solutions for the $21^{\text {st }}$ Century' the magazine Resurgence prepared for the Barcelona World Conservation Congress (Resurgence 250, 2008).

${ }^{10}$ An International Payment for Ecosystem Services (IPES), REDD (Reduced Emissions from Deforestation and Degradation) aims at curtailing deforestation in countries where the agricultural frontier is expanding dangerously. REDD represents a new global mechanism by which developed nations pay developing ones to maintain tropical forest carbon stores. REDD+ refers to REDD policies that propose to meet the opportunity, capacity-building and management costs of biodiversity
} 
question of indigeneity gains increased saliency with the new political battles for biodiversity conservation or resource development (Li 2010, Doolittle ms, Escobar 2008, Blaser 2009, de la Cadena 2010). However, the extent to which indigeneity - with its all its linguistic, territorial, identity, knowledge, and livelihood ramifications - is reshaping the narratives of biodiversity conservation and economic development is still unclear; cross-cultural comparative analyses of its political expressions have yet to be carried out. We also lack cross-cultural comparisons of regeneration practices and 'off human reach' spaces, with the unfortunate consequence that anti-conservationists remain convinced that biodiversity is a western obsession that has been discursively - if not coercively imposed on the rest of the world. To conciliate economic development with the preservation of nature represents one of the greatest political challenges of our times, a challenge that calls for a cultural revolution in the way we think about nature. It is therefore not surprising that a body of anthropological literature critical of the premises on which conservation areas are created is emerging (Surrallès and García Hierro 2004, Descola 2005). It is associated with calls for a politics based on ontological difference and cosmopolitan reason that will bring forth new ecological values and shared normative practices (de la Cadena 2010, Apffel-Marglin in press). ${ }^{11}$

The problem with conservation biology is not so much that it is 'genocentrist' (Escobar 2008: 140) or 'globo-obsessed' (Ingold 2001: 217), but, rather, that it was, until very recently, blind to the biological diversity of cultivated nature. When I started researching the cultural practices that enhance the genetic diversity of manioc (Manihot esculenta Crantz ssp.) among the Makushi of southern in Guyana (Rival and McKey 2008), a unique reserve of 371,000 hectares of ancient rainforest called Iwokrama had just been created in a part of their traditional territory. I will never forget the gaze of total puzzlement on the

conservation, while simultaneously addressing the need to sustain vital ecosystem services and to reduce rural poverty. For tensions between REDD and biodiversity conservation policies, see Putz and Redford (2009).

11 For a moving, subtle, and deeply insightful account of transcultural ecological thinking, see Kopenawa and Albert (2010). 
faces of the reserve's staff when the multi-disciplinary team with which I was collaborating presented its research project on manioc domestication. Their questions clearly indicated that, to them, researching biodiversity amounted to working on wildlife and pristine ecosystems with a view to discovering new species and protecting them from human interference. The exclusion of agrobiodiversity issues ${ }^{12}$ from conservation biology has meant that it took almost thirty years of research, engagement and contestation for the field to start acknowledging that regions untouched by capitalist development are not 'wild,' or that 'hotspots of biodiversity,' far from being pristine environments, have long been inhabited and transformed by humans - an awareness that climate change research has undoubtedly accelerated (Szabó 2010, Townsend 2008).

The panel on agrobiodiversity at the AMNH Symposium was by far the most stimulating, both theoretically and in policy terms. Sophie Caillon's analysis of how the history of cultivated plants parallels that of people in the Vanuatu village where she worked complemented Steven Brush's exposition of the role of culture in producing diversity and crop evolution (see also Brush 2004). Sophie Caillon convincingly showed that people are not conserving, but, rather, managing diversity, with different cultural practices co-existing in the same village, resulting in some crops being more genetically diverse than others (see also Caillon and Degeorges 2007, Caillon and Lanouguère-Bruneau 2005). Dominique Louette defined agrodiversity as the study of how organisms live in society, an approach allowing researchers to understand what farmers actually try to conserve, which also helps biologists define different conservation strategies for different levels of biological diversity. She stressed the importance of social learning. For instance, how farmers acquire seeds and knowledge, two key cultural factors often ignored by crop scientists, is consequential for the conservation processes that produce diversity (see also Louette et al 1997). Gary Paul Nabhan discussed seed preservation and exchange in the wider context of

\footnotetext{
12 Brookfield, who coined the term, defines agrobiodiversity as "diversity in the manner in which farmers use all their resources" (Brookfield 2001: xii). For many authors in the field, agrobiodiversity studies form an essential scientific component of the public debate about industrial agriculture and its impact on the environment (Stone 2010).
} 
food biodiversity. Having given a number of examples illustrating the fact that a focus on food processing allows researchers to include a wide range of microorganisms, as well as cultural practices, he concluded that a maximal level of interaction between biological and cultural diversity is found when taking into consideration the entire food system (see also Nabhan 2009). Miguel PinedoVázquez's focus on agroforestry systems as cultivated ecosystems demonstrated the benefits of broadening agrobiodiversity research beyond the analysis of field crops (see also Pinedo-Vázquez et al 2003). Christine Padoch stressed the need to conceptualise interactions between wild and cultivated biodiversity, especially at farm-level, given that the same biophysical factors affect both wild and cultivated diversity, and that farms include areas of semi-managed biodiversity, as well as transitional areas between wild and domesticated species. She gave examples of wild biodiversity preserved in traditional food production systems, and showed that the conservation of crop diversity is traditionally linked to the conservation of biological diversity more generally, the one implying the other (see also Brookfield and Padock 1994, Jarvis et al 2007). These anthropological studies richly demonstrate the biocultural diversity of cultivated nature (see also Ellen and Fukui 1996, Medin and Atran 1998, Nazarea 1998, 2005, Clement et al 2010). By making humans with their knowledge systems, values and interests always a part of the biodiversity story (Sponsel 2001, Toledo 2001), the anthropology of agrodiversity offers detailed empirical studies that challenge the three-tiered, hierarchical identification of diversity at the levels of genes, species and ecosystems more effectively than discourse deconstructions can ever do (Anderson and Berglund 2006, Carrier and West 2010).

\section{Valuing and governing biodiversity}

The general theme selected for the Barcelona World Conservation Congress (see footnote 7) was 'a diverse and sustainable world.' The objectives of the congress, as stated in official documents, were to: (1) demonstrate the 'links between natural and socio-cultural diversity and the role biodiversity plays in underpinning development; ' (2) show 'how the environment underpins all economic, social and cultural development;' and (3) promote 'economic tools and 
markets' to achieve 'positive change' through a 'new ethics based on ecosystem health and renewed environmental vitality.'13 The congress gathered at least 7000 delegates during a week or more. A team of about thirty ethnographers covered this large event. Publications based on their collective fieldwork are forthcoming (e.g. Brosius and Campbell in press, Doolittle ms). I do not know how the agenda of biocultural diversity fared at the congress - or since, but there is no doubt that the militant selling of 'payments for ecosystem services' as a necessary market mechanism to save biodiversity from destruction has gained considerable political clout since (e.g. Brokington 2010). 2010, declared the International Year of Biodiversity by the United Nations, ${ }^{14}$ has seen the release of several influential reports, in particular the TEEB (The Economics of Ecosystems and Biodiversity) study. ${ }^{15}$ A report from the United Nations Development Programme (UNDP) entitled 'Latin America and the Caribbean: A Biodiversity Superpower'16 released at Nagoya COP $10^{17}$ is already making waves. In the UK, a number of anthropologists (myself included) have been asked to participate in a $£ 40,5$ million multi-disciplinary research programme on 'Ecosystem Services for

\footnotetext{
${ }^{13}$ These quotes are from a document issued by the Congress Preparatory Committee on 23 March 2007.

${ }^{14}$ http://www.cbd.int/2010/welcome/.

${ }^{15}$ As indicated on the TEEB website (http://www.teebweb.org/), the TEEB study is a major international initiative which aims to: (1) draw attention to the global economic benefits of biodiversity; (2) highlight the growing costs of biodiversity loss and ecosystem degradation; and (3) draw together expertise from the fields of science, economics and policy to enable practical biodiversity conservation actions. Initially proposed by Germany, the TEEB study is hosted by UNEP with financial support from the European Commission, Germany, the United Kingdom, the Netherlands, Norway, Sweden and Japan. Funding for the TEEB study was agreed at a meeting of the environment ministers of the G8 countries and the five major newly industrialising countries that took place in Potsdam in March 2007. The study is led by Pavan Sukhdev, a senior banker from Deutsche Bank, and founder-director of the green accounting project "GIST" (Green Indian States Trust) in India. Mr. Sukhdev is currently on secondment with UNEP.

${ }^{16}$ Bovarnick, Alpizar and Schnell (2010), which reveals the continued influence of Costanza et al (1997).

${ }^{17}$ See Nagoya Biodiversity Summit's website at http://www.cbd.int/cop10, where an official declaration reads: 'Some 18,000 participants representing the 193 Parties to the Convention on Biological Diversity (CBD) and their partners closed the Nagoya Biodiversity Summit by adopting historic decisions that will permit the community of nations to meet the unprecedented challenges of the continued loss of biodiversity compounded by climate change. Governments agreed on a package of measures that will ensure that the ecosystems of the planet will continue to sustain human wellbeing into the future.' Less enthusiastic accounts by journalist commentators pointed to the absence of state officials (see http://www.cbd.int/doc/press/2010/pr-2010-10-29-cop-10-en.pdf.).
} 
Poverty Alleviation' (ESPA), ${ }^{18}$ whose cumbersome name nevertheless indicates the new directions taken by policy-oriented research on development, biodiversity, and the links between the two.

It is the positive value that biological diversity puts on all life on earth that makes it more than 'simply a new name for nature' (Farnham 2007: 7). As the idea of biodiversity embodies and generates moral principles (Takacs 1996: 286), it is not surprising that conservation biologists have worked hard at developing value taxonomies (Farnham 2007: 31). Takacs provides a fascinating discussion of how a new value vocabulary was developed to fight 'against biotic impoverishment' (Takacs 1996: 194). He convincingly shows that in trying to answer the question 'why we should value nature,' natural scientists have been grappling with the issue of how natural reality mixes - or not - with human labour. Takacs' fascinating discussion of the various values (scientific, ecological, social amenity or mutualism, biophilic, intrinsic, spiritual, and esthetic) mobilised by conservationists in the 1980s examines each in turn. He convincingly shows that conservationists were forced to develop an economic argument for biodiversity (i.e. 'make the business case for biodiversity') because economic value is the only language donors and the public would listen to (Takacs 1996: 208). However, most conservationists in fact believe deep down that love of nature is innate, or 'biophilic' (Takacs 1996: 218, Wilson 1984, Kellert and Wilson 1993). According to Takacs, conservationists turn to religion to cope with the contradiction between their belief in biophilia (i.e. the intrinsic value of biodiversity) and their real-world observations that biophilia is easily superseded by utilitarianism and greed. ${ }^{19}$

Although the biodiversity value debate is anthropologically

\footnotetext{
${ }^{18}$ See a description of this programme aimed at 'improving ecosystems management policies to help alleviate poverty in the developing world' at <http://www.nerc.ac.uk/research/programmes/espa/>. ESPA research, which is spondored by the Natural Environment Research Council (NERC), the Economic and Social Research Council (ESRC) and the Department for International Development (DfID) hopes to 'provide the evidence and tools to enable decision makers and end users to manage ecosystems sustainably and in a way that contributes to poverty reduction.'

19 Takacs quotes a biologist he interviewed, who told him that 'scientific analysis points toward the need for a quasi-religious transformation of contemporary cultures' (Takacs 1996: 254).
} 
fascinating, it has not received the attention it deserves (but see Posey 1999, Rival 2010), as analysts have preferred to focus their critical attention on the naïve utilitarianism and the imposition of globalised North American values that underlie the biodiversity discourse (e.g. Anderson and Berglund 2006, Carrier and West 2010, Harper 2005). Takacs himself concludes his insightful book with the remark: 'biologists feed into the very system that is destroying biodiversity by harnessing the forces of international business and labelling biodiversity another "resource" while leaving buried the causes of its destruction' (Takacs 1996: 282). This is exactly the line of analysis adopted by 'critical geographers' who research in the tradition of David Harvey and Noel Castree the impact of neoliberal capitalism on nature (e.g. Brockington and Duffy 2010, Igoe and Brockington 2007). Studies of 'the business of biodiversity' have multiplied, including in anthropological circles (e.g. Sullivan 2009). This body of political ecology work argues that, as predicted by ecological Marxists such as O'Connor (1988), conservation is instrumental to capitalism's growth and reproduction, for it turns environmental limits into new sources of capital. The financialisation of biodiversity conservation, like the 'financialisation of everything'(Harvey 2005: 33) else, brings forth the promise of new forms of accumulation. These studies offer useful insights in the political tensions surrounding the activities of international organizations such as the CBD (Convention on Biological Diversity) or the GEF (Global Environmental Facility), while shedding new light on the ideological struggle over the form that the international governance of biodiversity should take (MacDonald 2010). Corson's forty-year (1970-2010) reconstruction of the changing alliance between the US Congress, the US Agency for International Development (USAID) and four large US conservation nongovernmental organizations ${ }^{20}$ illustrates the circularity of funding flows irrigating an unusual public/private/non-profit partnership designed to conserve biodiversity in developing countries. ${ }^{21}$ Her study partly shows that

\footnotetext{
${ }^{20}$ The four NGOs, Conservation International (CI), the Wildlife Conservation Society (WCS),The Nature Conservancy (TNC), and WWF-US formed the International Conservation Partnership (ICP) in 2003.

${ }^{21}$ Corson cites a former USAID official who told her that it is easier to do biodiversity overseas than in this country because the conflicts don't involve constituencies of Congress' (Corson 2010: 592).
} 
'international biodiversity conservation is creating new symbolic and material spaces for global capital expansion' (Corson 2010: 578). However, her claim that conservation fuels the process of capitalist accumulation by creating new enclosures is not fully substantiated.

Corson's (2010) study helped me identify possible answers to questions that remained unsolved during my research on SUBIR, ${ }^{22}$ a large, ten-year USAIDfunded biodiversity conservation programme in the Ecuadorian Chocó. As my research was ethnographically located in Chachi and AfroEcuadorian communities along the river Cayapas, I could not, despite formal interviews with US-AID consultants, fully understand the reasons why this aid organization had suddenly decided in 1989 to single out biodiversity and forest conservation over issues that seemed to me more urgent in terms of development, such as soil erosion and agriculture, and which USAID had previously funded. My ethnographic research, however, illustrates how different the SUBIR programme was from the original design. SUBIR went through radical changes as it responded to the demands of Ecuadorian NGOs, indigenous organizations and villagers. It promoted community-owned cooperatives against the exploitative buying practices of logging companies. And if it triggered many political and economic debates around the valuation and pricing of timber, non-timber forest products, biological resources and ecosystem services, these were Ecuadorian debates, even if Ecuadorian conservationists were some times accused of being 'sold to the Yankees' by extractivists and resource nationalists. Biodiversity conservation, very much like international development, needs to be studied 'up' as well as from 'below,' and at many other levels of the policy network (e.g. Mosse 2005, Agrawal 2005, Orlove and Brush 1996). Corson's simplistic antineoliberal approach does not allow her to go beyond the surface of rhetorical pronouncements, or to engage the complex contexts in which rhetoric gets transformed into activities and processes on-the-ground (Tsing 2005, West 2005).

True, biodiversity conservation organizations have attempted to sell

\footnotetext{
22 Standing for 'Sustainable Use of Biological Resources.' See Rival (2003, 2005, 2007).
} 
themselves through a militant faith in market solutions to environmental problems. ${ }^{23}$ Whether they have convinced decision-makers and financers beyond the narrow circles of international development remains to be seen. Moreover, and as a number of studies have shown, what appears to be a market instrument is often realized as a more complex, hybrid mechanism (e.g. Kumar and Muradian 2009, Martinez-Alier 2009, Rival 2010). Furthermore, the neoliberal rhetoric creates its own antidote, and fuels anti-market mobilizations and anticapitalist protests all around the world, in which life, including the biological and cultural diversity of life, become potent sources of moral imagination and political inspiration (Rival 1998, Fernandez 1998). As already argued, discursive regimes (Fletcher 2010) and virtualism (Miller and Carrier 1998) cannot exhaust the analytical possibilities. Moreover, conservationism, like developmentalism, can no longer be seen as a western myth imposed on 'the rest,' for the rest actively shapes the world's future directions (Hulme 2010, Rival 2009, in press). ${ }^{24}$

\section{Oikos forever}

Development and biodiversity emerged as new ideas recombining older ones in the second half of the $20^{\text {th }}$ century - the former around 1950 , the latter thirty years later. Both have changed the way we see the world, and the way we act upon it. Both combine scientific ideas with moral ones (it can only be good to develop; the more diversity, the better). As exemplary 'boundary objects'

23 The best example has to be Daily and Ellison (2002)'s silly mantra 'nature has to pay for itself.'

${ }^{24}$ Here are four recent examples. It is in Brazil (and only there) that I heard: 'no one in human history has ever invented a development model for the tropics, we are going to!' India is the first country in the world to instate a national environmental accounting system, by which performance on environmental measures will become one of the criteria considered in the allocation of funds by the Planning Commission. In China, where the central government is actively supporting technological innovations in the field of renewable energy, more solar panels are being produced today than anywhere else in the world (Liu and Wang 2009). Ecuador's Yasuní Proposal to create an international fund in compensation for the non-exploitation of a large oil and gas field located in the Yasuní Biosphere Reserve for Humanity is formulated as a policy that will help the country's transition from an economic model based on short-sighted extractivism to one based on long-term sustainability. Moreover, the proposal shows the role that developing countries can play in global climate protection (Rival in press). 
comprising scientific facts and social constructions with 'deliberate and useful vagueness that makes it susceptible to a number of legitimate and potentially beneficial interpretations and reapplications' (Guyer and Richards 1996), development and biodiversity have provided excellent terrains for a range of deconstructivist projects. In social anthropology, Foucault's approach to power and knowledge, and, to a lesser extent, Latour's constructionist perspective on the networked relation between science and society have offered some of the most influential theoretical frameworks to apprehend the discursive effects of development and biodiversity. Ethnographers have provided invaluable accounts of the complex and highly dynamic processes of resistance, accommodation, domestication, or negotiated internalization that have occurred in many communities around the world during their encounters with either economic development or biodiversity conservation.

As I have tried to show in this chapter, late twentieth century thinking about sustainable development is slowly being recast within a new paradigm that proposes to replace older trade-offs between development and conservation with new hopes of 'developing while conserving.' As 'developing nations' develop and as the ecological crisis deepens, renewed efforts are made to recast the values underpinning economic development and biodiversity conservation. A new generation of economists is being trained in a new kind of economic thought, ecological economics (e.g. Daly and Farley 2004), which, it is hoped, will lead to a new way of making development decisions by incorporating the values fact that Nature provides for human livelihood, biodiversity, and resilience of ecosystems. The problem, long understood by some thinkers (O'Neill 2007) is that such values cannot easily be translated into money terms. They require the development of multi-criteria methods that seek to avoid economic reductionism by integrating social and environmental factors in the units of measurements. The re-evaluation of nature that characterises this new regime of value deserves serious anthropological attention. Anthropologists will need to address through ethnographic enquiry the complex links between ecosystems, biological diversity, economic development, human needs, aspirations, and political struggles. In addition to obvious epistemological tensions between 
poststructuralist and ethnobiological explanations of nature (Escobar 2008, Ellen 2010), anthropologists will need to account for the co-existence of selfinterested calculation and commitment to values. Could value and interest ever be brought in line? For some authors, this duality overlaps with the tension between 'materialism' and 'spiritual' (Apffel-Marglin 2008); for others, wary of systemic explanations, it corresponds to the tension between 'individual' and 'society' (Hastrup 2009). Anthropologists, who on the whole have shied away from the sustainability debate, may soon realise that conversations around responsibilities for the maintenance of the earth's commons raise fundamental anthropological questions, including that of engaged anthropology (Low and Merry 2010). As anthropological research is predicated on the dilemmas of portraying the 'native point of view' without having necessarily to share it, researchers will have to find ways of examining commitments to values that are deeply implicated in our common future from a range of locations and perspectives. This will necessitate, at the very least, a renewal of our discipline's comparative project.

\section{REFERENCES}

Adams, W. et al. 2004. Biodiversity conservation and the eradication of poverty. Science 306: 1146-1149.

Agrawal, A. 2005. Environmentality. Technologies of government and the making of subjects. Durham: Duke University Press.

Anderson, D. and E. Berglund (eds.). 2006. Ethnographies of conservation: environmentalism and the distribution of privilege. New York: Berghahn Books.

Apffel-Marglin, F. 2008. Rhythms of life: enacting the world with the goddesses of Orissa. Delhi: Oxford University Press.

in press. Subversive spiritualities: how rituals enact the world. New York: Oxford University Press.

Asad, T. (ed.). 1973. Anthropology and the colonial encounter. London: Ithaca Press. 
Atran S. 1999. Itzaj Maya folkbiological taxonomy: cognitive universals and cultural particulars. In Folkbiology. (eds) D. Medin and S. Atran, 119-204. Cambridge, Mass.: MIT Press.

Balée, W. 2006. The research programme of historical ecology. Annual Review of Anthropology 35: 75-98.

Blaser, M., 2009. The threat of the Yrmo: the political ontology of a sustainable hunting program. American Anthropologist 111 (1): 10-20.

Bovarnick, A., F. Alpizar, C. Schnell (eds). 2010. The importance of biodiversity and ecosystems in economic growth and equity in Latin America and the Caribbean: an economic valuation of ecosystem. New York: UNDP (United Nations Development Programme).

Brokington, D. 2010. Guest Editor. Antipode 42(3) special issue on biodiversity conservation.

Brockington, D. and R. Duffy. 2010. Capitalism and conservation: the production and reproduction of biodiversity conservation. Antipode 42(3): 469-484.

Brookfield, H. C. 2001. Exploring agrodiversity. New York: Columbia University Press.

Brookfield, H. C. and C. Padoch. 1994. Appreciating agrodiversity: a look at the dynamism and diversity of indigenous farming practices. Environment 36(5): 6$11,37-45$.

Brosius, J. P. 2004. Indigenous peoples and protected areas at the World Parks Congress. Conservation Biology 18: 609-612.

Brosius, J. P. and L. Campbell. In press. Collaborative event ethnography: conservation and development trade-offs at the 4th world conservation congress. Conservation and Society **.

Brosius, P., A. Lowenhaupt Tsing, and C. Zerner (eds.). 2005. Communities and conservation: histories and politics of community-based natural resource management. Walnut Creek, CA: AltaMira Press.

Brush, S. 2004. Farmers' bounty. Locating crop diversity in the contemporary world. New Haven: Yale University Press.

Caillon, S. and P. Degeorges. 2007. Biodiversity: negotiating the border between nature and culture. Biodiversity Conservation 16(10): 2919-2931.

Caillon, S. and V. Lanouguère-Bruneau. 2005. Gestion de l'agrobiodiversité dans un village de Vanua Lava (Vanuatu). Journal de la Société des Océanistes 120/121: 129-148. 
Carrier, J. and P. West (eds). 2010. Virtualism, governance and practice. Vision and execution in environmental conservation. Oxford: Berghahn Books.

Clement, C., L. Rival and D. M. Cole. 2009. Domestication of peach palm (Bactris Gasipaes Kunth): the roles of human mobility and migration. In The ethnobiology of mobility, displacement and migration in indigenous lowland South America. (ed.) Miguel Alexiades, 117-140. Oxford: Berghahn Books.

Clement, C. et al. 2010. Origin and domestication of native Amazonian crops. Diversity 2: 72-106.

Cohen, M. P. and R. W. Shenton. 1996. Doctrines of development. London: Routledge.

Cooper F. and R. Packard (eds). 1997. International development and the social sciences: essays on the history and politics of knowledge. Berkeley, CA: University of California Press.

Costanza, R. et al. 1997. The Value of the World's Ecosystem Services and Natural Capital. Nature 387:253-260.

Corson, C. 2010. Shifting environmental governance in a neoliberal world: US AID for conservation. Antipode 42(3): 576-602.

Crush, J. (ed.). 1995. Power of Development. New York: Routledge.

Daily, G. and K. Ellison. 2002. The new economy of nature. The quest to make conservation profitable. Washington, D.C.: Island Press.

Daly, H. and J. Farley. 2004. Ecological Economics. Principles and Applications. Washington. D.C.: Island Press.

De la Cadena, M. 2010. Indigenous cosmopolitics in the Andes: conceptual reflections beyond 'politics.' Cultural Anthropology 25 (2): 334-370.

Descola, P. 2005. Par-delà nature et culture. Paris: Gallimard.

Doolittle, A. 2010. The politics of indigeneity: indigenous strategies for inclusion in climate change negotiations. Ms.

Dressler, W. et al. 2010. From hope to crisis and back again? A critical history of the global CBNRM narrative. Environmental Conservation 37(1): 5-15.

Ellen, R. F. 2010. Theories in anthropology and 'anthropological theory.' Journal of the Royal Anthropological Institute (N.S.) 16(3): 387-404.

Ellen, R. F. and K. Fukui (eds). 1996. Redefining nature. Ecology, culture and domestication. Oxford: Berg. 
Escobar, A. 2008. Territories of difference. Place, movements, life, redes. Durham: Duke University Press.

Farnham, T. 2007. Saving nature's legacy. Origins of the idea of biodiversity. New Haven: Yale Unievrsity Press.

Fernandez, J. 1998. ***. In The social life of trees. Anthropological perspectives on tree symbolism (ed.) Laura Rival, *_*. Oxford: Berg.

Filer, C. 2010. A bridge too far: the knowledge problem in the Millenium Assessment. In Virtualism, governance and practice. Vision and execution in environmental conservation. J. Carrier, J. and P. West (eds), 84-111. Oxford: Berghahn Books.

Fletcher, R. 2010. Neoliberal environmentality: towards a post-structuralist political ecology of the conservation debate. Conservation and Society 8(3): 171181.

Flyvbjerg, B. 2001. Making social science matter: why social inquiry fails and how it can succeed again. Cambridge University Press

Graef, D. et al. 2008. The cultural politics of sustaining diversity. Background paper prepared by the Dove/ Carpenter lab at Yale University. Ms.

Guha, R. and J. Martinez-Alier. 1997. Varieties of environmentalism: essays North and South. Delhi: Oxford University Press.

Guyer, J. and P. Richards. 1996. The invention of biodiversity: social perspectives on the management of biological diversity in Africa. Africa 66(1): 1-13.

Harper, K. 2005. 'Wild capitalism' and 'ecocolonialism': a tale of two rivers. American Anthropologist 107(2): 221-233.

Harvey, D. 2005. A brief history of neoliberalism. Oxford: Oxford University Press. Hastrup, K. 2009. Waterworlds: framing the question of social resilience. In The question of resilience. Social responses to climate change (ed.) K. Hastrup, 11-30. Copenhagen: The Royal Danish Academy of Sciences and Letters.

Howell, S. 2010. Norwegian academic anthropologists in public spaces. Current Anthropology 51(S2): S269-S277.

Hulme, M. 2010. Cosmopolitan climates. Hybridity, foresight and meaning. Theory, Culture and Society 27(2-3): 267-276.

Igoe, J. and D. Brockington. 2007. Neoliberal conservation: a brief introduction. Conservation and Society 5(4): 432-449

Ingold, T. 2001. The perception of the environment. Essays in livelihood, dwelling and skill. London: Routledge. 
Jarvis, D. I., C. Padoch, and D. Cooper (eds). 2007. Managing biodiversity in agricultural ecosystems. New York: Columbia University Press.

Kaua'i Declaration, The. 2007. Economic Botany 61(1): 1-2.

Kellert, S. and E. O. Wilson (eds). The biophilia hypothesis. Washington. D.C.: Island Press. 1993.

Kopenawa, D. and B. Albert. 2010. La Chute du ciel. Paroles d'un chaman yanomami. Paris: Plon, Collection Terre Humaine.

Kumar, P. and R. Muradian (eds). 2009. Payment for ecosystem services. Delhi and Oxford: Oxford University Press.

Li, T. 2010. Indigeneity, capitalism, and the management of dispossession. Current Anthropology 51(3): 385-414.

Liu, L. and Z. Wang. 2009. The development and application practice of windsolar energy hybrid generation systems in China. Renewable and Sustainable Energy Reviews 13: 1504-1512.

Lockyer, J. and J. R. Veteto (eds). in press. Environmental anthropology engaging ecotopia. Bioregionalism, permaculture and ecovillages for the sustainable future. Oxford: Berghahn.

Louette, D., A. Charrier and J. Berthaud. 1997. In Situ conservation of maize in Mexico: Genetic diversity and Maize seed management in a traditional community. Economic Botany 51(1): 20-38.

Low, S. M. and S. E. Merry. 2010. Engaged anthropology: diversity and dilemmas. Current Anthropology 51(S2): S203-S225.

MacDonald, K. I. 2010. The devil is in the (bio)diversity: private sector "engagement" and the restructuring of biodiversity conservation. Antipode 42(3): 513-550.

Maffi, L. 2005. Linguistic, cultural, and biological diversity. Annual Review of Anthropology 34: 599-617.

Maffi, L. (ed.). 2001. On biocultural diversity. Linking language, knowledge and the environment. Washington, D.C.: Smithsonian Institution Press.

Martinez-Alier, J. 2002. The Environmentalism of the Poor. A study of ecological conflicts and valuation.

----- 2009. Social metabolism, ecological distribution conflicts, and languages of valuation. Capitalism, Nature, Socialism 20(1): 58-87. 
Medin, D. and S. Atran (eds). 1999. Folkbiology. Cambridge, Mass.: MIT Press.

Millenium Ecological Assessment. 2005. Ecosystems and human well-being: biodiversity synthesis. Washington, DC: World Resources Institute.

Miller, D. and J. Carrier (eds). 1998. Virtualism, a new political economy. Oxford: Berg.

Mosse, D. 2005. Cultivating development: an ethnography of aid policy and practice. London: Pluto Press

Nabhan, G. P. 2009. Where our food comes from: retracing Nikolay Vavilov's quest to end famine. Washington, D.C. : Island Press.

Nazarea, V. 1998. Cultural memory and biodiversity. Tucson, AZ: University of Arizona Press.

2005. Heirloom seeds and their keepers. Marginality and memory in the conservation of biological diversity. Tucson, AZ: University of Arizona Press.

Norgaard, R. B. 2008. Finding hope in the Millennium Ecosystem Assessment, Conservation Biology 22: 862-869.

O'Connor, J. 1988. Capitalism, nature, socialism: a theoretical introduction. Capitalism, Nature, Socialism 1: 11-38.

O’Neil, J. 2007. Markets, deliberation and environment. London: Routledge.

Orlove, B. and S. Brush. 1996. Anthropology and the Conservation of Biodiversity. Annual Review of Anthropology 25: 329-352.

Paulson, N. et al. in press. Indigenous peoples participation in global conservation: looking beyond headdresses and face paint. Conservation and Society Journal **

Pinedo-Vázquez, M. et al. 2003. Peru. In Agrodiversity: learning from farmers across the world. (eds) H. Brookfield, H. Parsons and M. Brookfield, 232-248. Tokyo: United Nations University Press.

Posey, D. (ed.). 1999. Cultural and spiritual values of biodiversity. A complementary contribution to the global diversity assessment. Nairobi: UNEP and IT Publication.

Putz, F. E. and K. H. Redford. 2009. Dangers of carbon-based conservation. Global Environmental Change 19: 400-401.

Redford, K. H. and J. P. Brosius. 2006. Diversity and homogenization in the endgame. Editorial. Global Environmental Change 16: 317-319. 
Rival, L. .1998. Trees from symbols of life and regeneration to political artefacts. The social life of trees. Anthropological perspectives on tree symbolism. (ed.) Laura Rival, 1-36. Oxford: Berg.

2003. The meanings of forest governance in Esmeraldas, Ecuador. Oxford Development Studies 31(4): 479-501.

----- 2005. From global forest governance to privatized social forestry: companycommunity partnerships in the Ecuadorian Chocó. In Privatizing development: transnational law, infrastructure and human rights. (ed.) Michael B. Likosky, 253270. London: Brill Academic Publishing.

----- 2006. Amazonian historical ecologies. In Ethnobiology and the science of humankind. A retrospective and a prospective (ed.) Roy Ellen, 97-116. Special issue of JRAI \# 1.

---- 2007. Partnerships for sustainable forest management: lessons from the Ecuadorian Chocó. In Partnerships in sustainable forest resource management: learning from Latin America. (eds) Mirjam Ros-Tonen, H. van den Hombergh and A. Zoomers, 37-62. Amsterdam: CEDLA.

---- 2009. The resilience of indigenous intelligence. In The question of resilience. Social responses to climate change (ed.) K. Hastrup, 293-313. Copenhagen: The Royal Danish Academy of Sciences and Letters.

---- 2010. Ecuador's Yasuní-ITT Initiative: the old and new values of petroleum. Ecological Economics 70: 358-365.

in press. Planning development futures in the Ecuadorian Amazon: the expanding oil frontier and the Yasuní-ITT Initiative. In Extractive economies, socio-environmental conflicts and territorial transformations in the Andean Region (ed.) A. Bebbington. Pp.*-*. Pittsburgh, PA: University of Pittsburgh Press.

Rival, L. and D. McKey. 2008. Domestication and diversity in manioc (Manihot esculenta Crantz ssp. esculenta, Euphorbiaceae ). Current Anthropology 49(6): 1119-28.

Spencer, J. 2010. The perils of engagement. A space for anthropology in the age of security? Current Anthropology 51(S2): S289-S299.

Sponsel, L. E. 2001. Human impact on biodiversity, overview. In Encyclopedia of Biodiversity (ed.) Simon Asher Levin, 3: 395-409. San Diego, CA: Academic Press.

Stone, G. D. 2010. The anthropology of genetically modified crops. In Annual Reviews of Anthropology 39: 381-400.

Sullivan, S. 2009. Green capitalism. Radical Anthropology 3: 18-27.

Surrallès, A. and P. García Hierro (eds). 2004. Tierra adentro. Territorio Indígena y percepción del entorno. Copenhagen: IWGIA (Document 39). 
Szabó, P. 2010. Why history matters in ecology: an interdisciplinary perspective. Environmental Conservation 37(4): 380-387.

Takacs, D. 1996. The idea of biodiversity: philosophy of paradise. Baltimore: The John Hopkins University Press.

Toledo, V. M. 2001. Biodiversity and indigenous peoples. In Encyclopedia of Biodiversity (ed.) Simon Asher Levin, 3: 451-463. San Diego, CA: Academic Press.

Townsend, C. 2008. Ecological applications. Toward a sustainable world. Oxford: Blackwell.

Tsing, A. L. Friction: an ethnography of global connection. Princeton: Princeton University Press.

West, P. 2005. Translation, value, and space: theorizing an ethnographic and engaged environmental anthropology. American Anthropologist 107(4): 632-642.

Wilson, E. O. 1984. Biophilia: the human bond with other species. Cambridge, MA: Harvard University Press.

---- 1985. The biological diversity crisis: a challenge to science. Issues in Science and Technology 2: 20-29.

Wilson, E. O. (ed.). 1988. BioDiversity. Washington, D.C.: National Academic Press.

Zerner, C. (ed.). 2000. People, plants and justice. The politics of nature conservation. New York: Columbia University Press. 